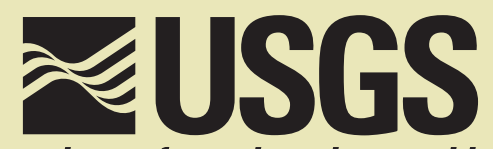

science for a changing world

\title{
Woody Riparian Vegetation near Selected Streamgages in the Western United States
}

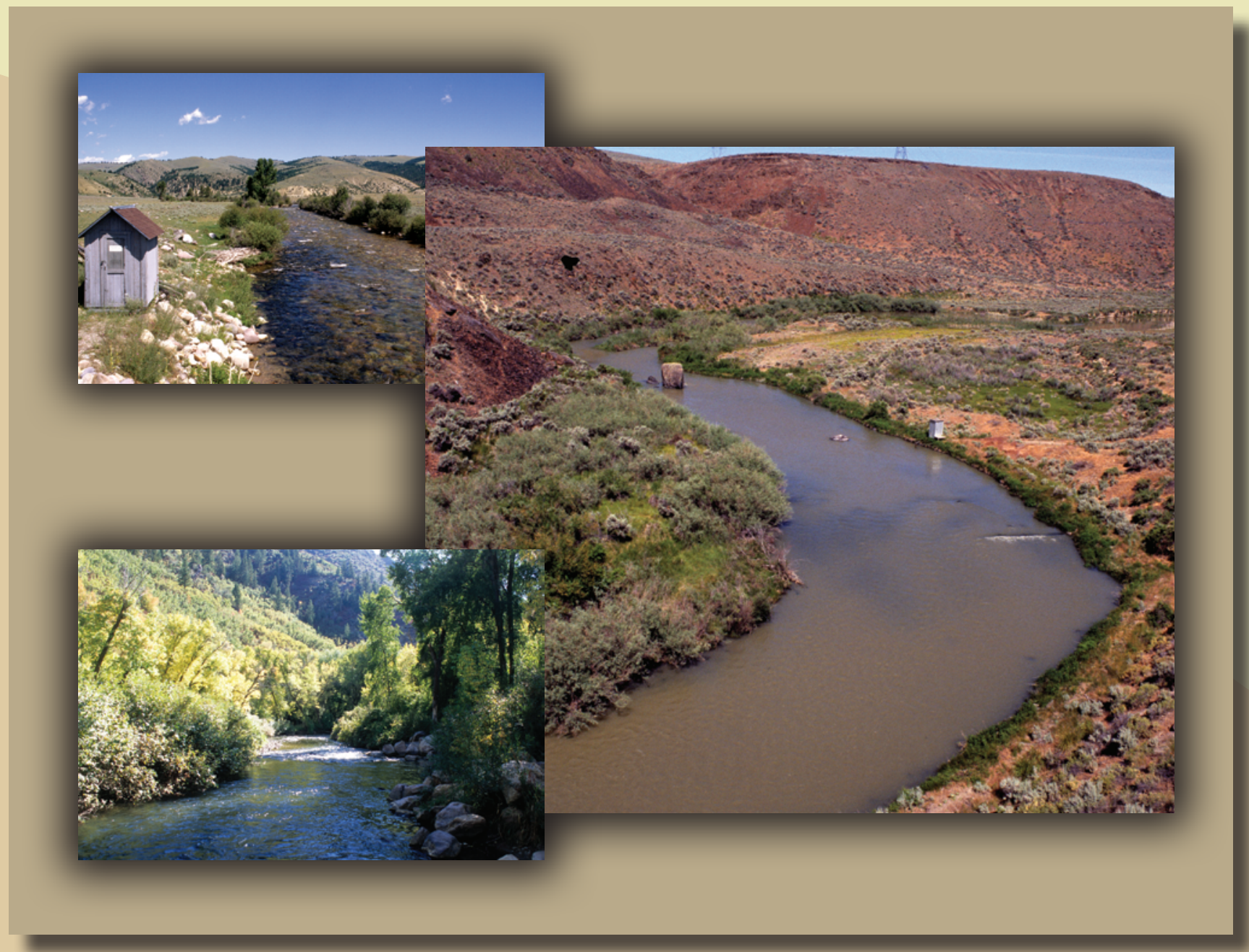

Data Series 708

U.S. Department of the Interior

U.S. Geological Survey 



\section{Woody Riparian Vegetation near Selected Streamgages in the Western United States}

By Gregor T. Auble, Jonathan M. Friedman, Patrick B. Shafroth, Michael F. Merigliano, and Michael L. Scott

Data Series 708 


\section{U.S. Department of the Interior \\ KEN SALAZAR, Secretary \\ U.S. Geological Survey \\ Marcia K. McNutt, Director}

\section{U.S. Geological Survey, Reston, Virginia: 2012}

For more information on the USGS - the Federal source for science about the Earth, its natural and living resources, natural hazards, and the environment, visit http://www.usgs.gov or call 1-888-ASK-USGS.

For an overview of USGS information products, including maps, imagery, and publications,

visit http://www.usgs.gov/pubprod

To order this and other USGS information products, visit http://store.usgs.gov

Any use of trade, firm, or product names is for descriptive purposes only and does not imply endorsement by the U.S. Government.

Although this information product, for the most part, is in the public domain, it also may contain copyrighted materials as noted in the text. Permission to reproduce copyrighted items must be secured from the copyright owner.

Suggested citation:

Auble, G.T., Friedman, J.M., Shafroth, P.B., Merigliano, M.F., and Scott, M.L., 2012, Woody riparian vegetation near selected streamgages in the western United States: U.S. Geological Survey Data Series 708, 8 p. 


\section{Contents}

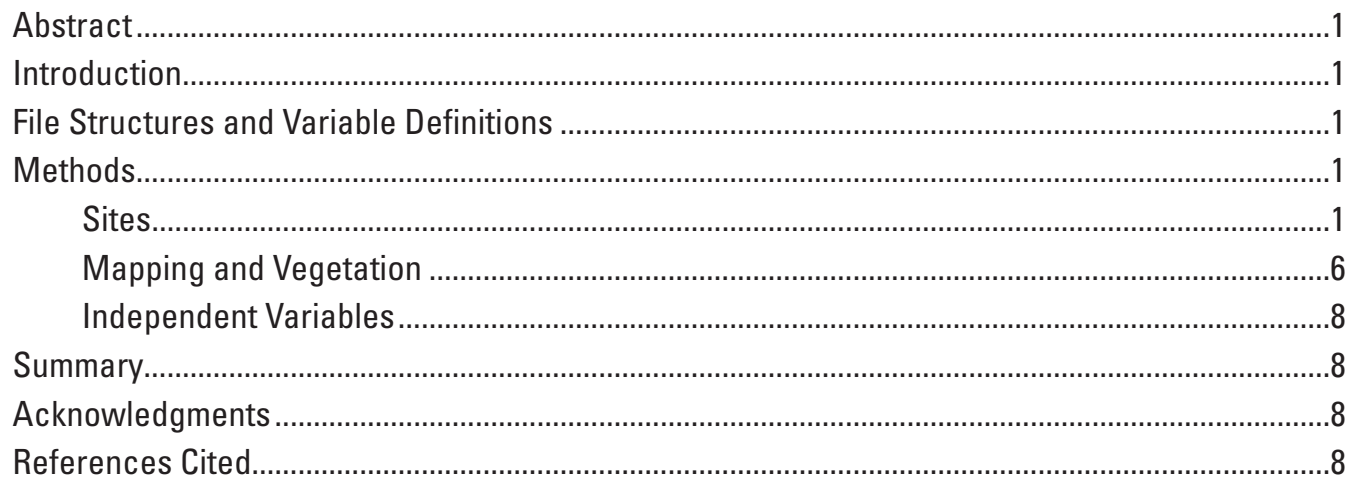

\section{Figures}

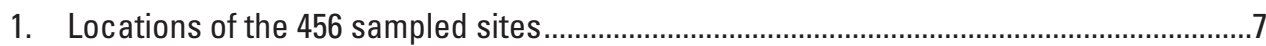

\section{Tables}

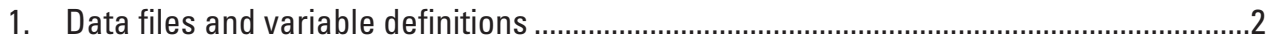

2. Codes used for vegetation species and cover mapping classes ........................................ 


\section{Conversion Factors}

SI to Inch/Pound

\begin{tabular}{lcl}
\hline \multicolumn{1}{c}{ Multiply } & By & \multicolumn{1}{c}{ To obtain } \\
\hline millimeter $(\mathrm{mm})$ & Length & \\
meter $(\mathrm{m})$ & 0.03937 & inch (in.) \\
kilometer $(\mathrm{km})$ & 3.281 & foot (ft) \\
meter $(\mathrm{m})$ & 0.6214 & mile (mi) \\
& 1.094 & yard (yd) \\
\hline square meter $\left(\mathrm{m}^{2}\right)$ & Area & acre \\
square kilometer $\left(\mathrm{km}^{2}\right)$ & 0.0002471 & acre \\
square meter $\left(\mathrm{m}^{2}\right)$ & 247.1 & square foot $\left(\mathrm{ft}^{2}\right)$ \\
square kilometer $\left(\mathrm{km}^{2}\right)$ & 10.76 & square mile $\left(\mathrm{mi}^{2}\right)$ \\
\hline
\end{tabular}




\title{
Woody Riparian Vegetation near Selected Streamgages in the Western United States
}

\author{
By Gregor T. Auble, ${ }^{1}$ Jonathan M. Friedman, ${ }^{1}$ Patrick B. Shafroth,, Michael F. Merigliano, ${ }^{2}$ and \\ Michael L. Scott ${ }^{1}$
}

\section{Abstract}

We visited and recorded occupancy and areal cover of woody riparian species near 456 streamgages in the western United States during the growing seasons of 1996-2002. We made concomitant estimates of grazing intensity, channel stabilization and incision, gradient, sediment particle size, and nearby planting of Russian olive. The purpose of this publication is to describe the data set and make it available to other investigators in an electronic format.

\section{Introduction}

Much of the understanding of relationships between streamflow and riparian vegetation comes from observations of spatial and temporal patterns at one site, or from a relatively small set of sites in a restricted geographic area. Applying the results of these studies of restricted areas to new locations and properly generalizing the determinants of broad patterns can be challenging. One approach to identifying general patterns is to examine spatially extensive data sets of riparian vegetation with species-level resolution, consistent methods, and concomitant long-term hydrologic records; however, these data sets are rare. In order to develop this kind of data set we visited and recorded riparian vegetation associated with over 450 U.S. Geological Survey (USGS) streamgages across 17 states in the western United States. The purpose of this publication is to describe the data set and make it available to other investigators in an electronic format.

\section{File Structures and Variable Definitions}

Data are organized in six separate, comma delimited files (*.csv) with a header line containing variable names (table 1). These are archived with this report in downloadable,

\footnotetext{
${ }^{1}$ U.S. Geological Survey
}

${ }^{2}$ University of Montana electronic form; however, merging and reshaping the data will likely be required for analysis. There are two fields common to multiple files. GAGE is the USGS streamgage identification number linked to USGS streamflow records (U.S. Geological Survey 2012). SPPCODE represents the taxonomic units and cover types that we recognized. We recorded cover and occupancy only for entries on this pre-defined list (table 2). The list does, however, define a mixed set of individual valid species, conflations or pooling of valid species, separate age classes for selected single valid species, and placeholders for conditions such as no species present or excluded areas such as roads and cropland.

Naturally occurring woody species $>1.5 \mathrm{~m}$ tall that were not included in the standard list were pooled into the class of Other Large Woody (SPPCODE = OLW, table 2). In general, nomenclature follows U.S. Department of Agriculture (USDA), 2004. There were several conflations of species that were difficult to distinguish in the field. The largest groups were Prunus spp. (SPPCODE = PRUSPE, table 2) representing all plums and cherries and Salix spp. (SPPCODE $=$ SALSPP, table 2) representing all willow except for the recognized Salix amygdaloides, Salix bonplandiana, Salix exigua (itself a conflation of several species), Salix gooddingi, and Salix x rubens. We distinguished only two types of Tamarix: Tamarix aphylla and Tamarix ramosissima with T. ramosissima including $T$. chinensis and hybrids. Cottonwood species (Populus angustifolia, P. deltoides ssp. monolifera, and $P$. deltoides ssp. wislizeni) were each subdivided into estimated age classes of $\leq 30$ years and $>30$ years for both cover and occupancy. Age was estimated based on bark characteristics and size. These classes must be combined to calculate overall site cover or occupancy for the respective species.

\section{Methods}

\section{Sites}

This data set is based on site visits to 456 streamgages carried out during the growing seasons of 1996-2002 (fig. 1). We selected USGS streamgages within a 17 -state region of 


\section{Woody Riparian Vegetation near Selected Streamgages in the Western United States}

Table 1. Data files and variable definitions. Information in this table is also contained in electronic fileVARIABLESandFILES.pdf.

\begin{tabular}{clll}
\hline File & \multicolumn{1}{c}{ Variable } & \multicolumn{1}{c}{ Values } & \multicolumn{1}{c}{ Description } \\
\hline Occupy.csv & & & \\
& GAGE & Gage number & USGS gage number without leading zeros \\
SPPCODE & Character species code & $\begin{array}{c}\text { Species code as defined in table 1 and file SppList.csv; SPPCODE of NONE indicates } \\
\text { no woody species at site }\end{array}$ \\
& PRESENT & 1 & $\begin{array}{c}\text { Present; no entries for species not present; 1 for SPPCODE of NONE indicates no } \\
\text { woody species at site }\end{array}$
\end{tabular}

Gages.csv

$\begin{array}{lll}\text { GAGE } & \text { Gage number } & \text { USGS gage number without leading zeros } \\ \text { RIVER } & \text { River name } & \text { Character; may include embedded spaces } \\ \text { LONG } & \text { Decimal degrees } & \text { Longitude in decimal degrees; from gage description NAD83 } \\ \text { LAT } & \text { Decimal degrees } & \text { Latitude in decimal degrees; from gage description NAD83 } \\ \text { ALTITUDE } & \text { Meters } & \text { Altitude; from gage description NGVD29 }\end{array}$

Indicators.csv

\begin{tabular}{|c|c|c|}
\hline GAGE & Gage number & USGS gage number without leading zeros \\
\hline YYYY & Year & Year sampled \\
\hline MM & Month & Month (1-12) sampled \\
\hline LSTABLE & Decimal fraction & Fraction of left bank (looking downstream) with anthropogenic bank stabilization \\
\hline RSTABLE & Decimal fraction & Fraction of right bank (looking downstream) with anthropogenic bank stabilization \\
\hline FPSED & $\mathrm{D}_{50}$ in millimeters & Estimate of floodplain sediment size class, value of 99999 is bedrock \\
\hline \multirow[t]{5}{*}{ GZHERB } & Classification of 1-4 & Classification of current herbaceous grazing indicators \\
\hline & 1 & Seed heads of cool and warm season grass species intact \\
\hline & 2 & $\begin{array}{l}\text { Seed heads of cool season grasses present but scattered-visible feces less than } 1 \text { year } \\
\text { old }\end{array}$ \\
\hline & 3 & Most herbaceous species obviously grazed-but stubble heights obscure the ground \\
\hline & 4 & $\begin{array}{l}\text { All herbaceous species are grazed so close to the ground that feces become very } \\
\text { prominent }\end{array}$ \\
\hline \multirow[t]{3}{*}{ GZSHRUB } & Classification of $1-2$ & Classification of current shrub grazing indicators \\
\hline & 1 & Existing shrubs intact \\
\hline & 2 & Existing shrubs show some recent use, leaves stripped off; some young twigs clipped \\
\hline \multirow[t]{5}{*}{ GZPAST } & Classification of $1-4$ & Classification of past use grazing indicators \\
\hline & 1 & Shrubs show little to no browsing; Regeneration present on suitable sites \\
\hline & 2 & $\begin{array}{l}\text { Shrubs, especially those known to be palatable, show browse patterns; Shrub and tree } \\
\text { regeneration present; Weedy annual or biennial species typically prominent }\end{array}$ \\
\hline & 3 & $\begin{array}{l}\text { Shrubs widely scattered, crowns reduced and shaped by browsing (flat-topped or } \\
\text { umbrella-shaped); Weedy annual or biennial species typically present but may not } \\
\text { be noticeable due to grazing }\end{array}$ \\
\hline & 4 & $\begin{array}{l}\text { Few to no shrubs where expected; other indicators of long and high grazing use pres- } \\
\text { ent such as: Animal trails well-defined and shade-up areas have trampled appear- } \\
\text { ance and bare soil; } \\
\text { Bank trampling is well-distributed and not restricted to local areas; } \\
\text { All herbaceous species are grazed so close to the ground that feces become very } \\
\text { prominent; } \\
\text { If winter-grazed, known invader and increaser species are prominent }\end{array}$ \\
\hline
\end{tabular}


Table 1. Data files and variable definitions. Information in this table is also contained in electronic file VARIABLESandFILES.pdf. -Continued

\begin{tabular}{|c|c|c|c|}
\hline File & Variable & Values & Description \\
\hline & EPLANT & $1=$ Yes; $0=$ No & Was planted ELEANG observed within $5 \mathrm{~km}$ of site \\
\hline & TPLANT & $1=$ Yes; $0=\mathrm{No}$ & Was planted TAMRAM observed within $5 \mathrm{~km}$ of site \\
\hline & DOWN & $1=$ Yes; $0=$ No & $\begin{array}{l}\text { Has there been notable and obvious downcutting or channel narrowing in the last } 150 \\
\text { years }\end{array}$ \\
\hline \multicolumn{4}{|c|}{ Geometry.csv } \\
\hline & GAGE & Gage number & USGS gage number without leading zeros \\
\hline & SITEAREA & $\mathrm{km}^{2}$ & Total mapped study area \\
\hline & CHANAREA & $\mathrm{km}^{2}$ & River channel area in mapped study area \\
\hline & CHANLEN & $\mathrm{km}$ & Length of river channel in mapped study area \\
\hline & & 1 & Normal estimation using topographic maps of larger area \\
\hline & & 2 & Estimation limited to mapped study site area \\
\hline & & 3 & Estimate is a maximum where gradient was very shallow \\
\hline & & 4 & zero gradient assigned when study site was actually linear reservoir section \\
\hline \multicolumn{4}{|c|}{ CoverArea.csv } \\
\hline & GAGE & Gage number & USGS gage number without leading zeros \\
\hline & POLYNO & Polygon ID number & Polygon identification number \\
\hline & POLYAREA & $\mathrm{km}^{2}$ & Polygon area; same for all SPPCODE rows for a given POLYNO \\
\hline & TYPE & Classification of $1-5$ & \\
\hline & & 1 & Valid species \\
\hline & & 2 & Age class of single valid species \\
\hline & & 3 & Conflation of 2 or more valid species \\
\hline & & 4 & Species not on species list; OLW for Other Large Woody \\
\hline & & 5 & Other type: channel; bare ground; excluded polygon; no species \\
\hline & SCINAME & Character species name & Species name and authority; no italics; Some entries are placeholders not species \\
\hline & NOTES & Character & Common name and notes if any \\
\hline
\end{tabular}


Table 2. Codes used for vegetation species and cover mapping classes. This table is the contents of electronic file SppList.csv. Nomenclature follows USDA (2004).

[SPPCODE is acronym used for classes of vegetation and cover type. Values of TYPE are: $1=$ Valid species; $2=$ Age class of single valid species; $3=$ Conflation of two or more valid species; $4=$ Species not on species list and thus included as other large woody; $5=$ Other cover type, including channel, excluded polygon, bare or no woody species present. NOTES contains common name of species and clarifying text]

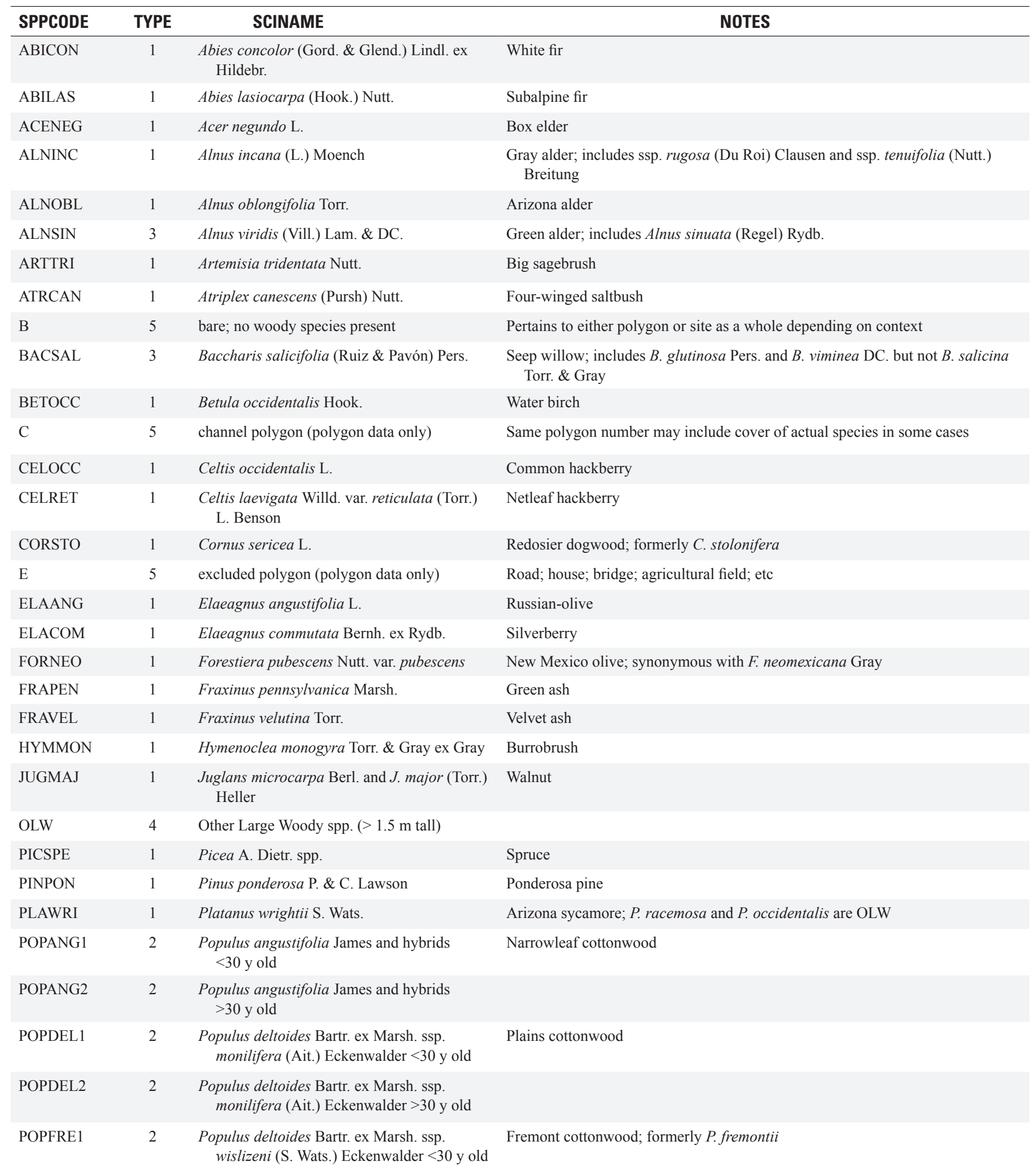


Table 2. Codes used for vegetation species and cover mapping classes. This table is the contents of electronic file SppList.csv. Nomenclature follows USDA (2004)._-Continued

[SPPCODE is acronym used for classes of vegetation and cover type. Values of TYPE are: $1=$ Valid species; $2=$ Age class of single valid species; $3=$ Conflation of two or more valid species; $4=$ Species not on species list and thus included as other large woody; $5=$ Other cover type, including channel, excluded polygon, bare or no woody species present. NOTES contains common name of species and clarifying text]

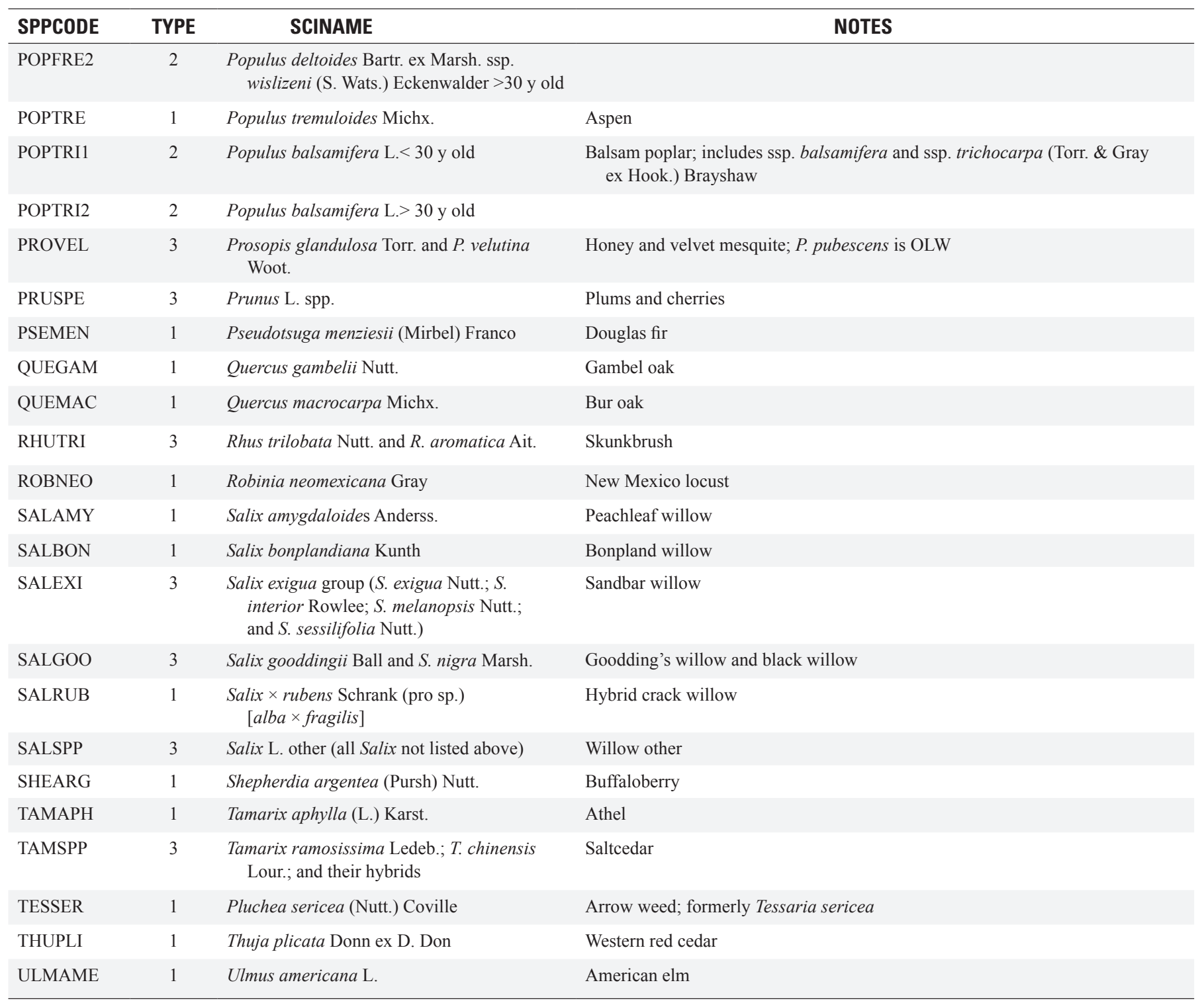


the United States bounded on the east by the $100^{\circ} \mathrm{W}$ longitude line (the 100th meridian west), and on the west by the approximate crest of the Sierra Cascade Mountains. We further restricted the potential gages to those with daily discharge data for at least 20 of the years between 1965 and 1994. This set contained approximately 1,500 streamgages from which we carried out a weighted random selection of 500 .

Streamgage locations are not randomly distributed across the landscape or within a river network. For example, they tend to be located to measure sources of water supply (for example, rivers draining mountains with snowpack in the western U.S.); to evaluate water management (for example, near reservoirs and diversions); and where rivers cross jurisdictional boundaries (for example, into or out of Canada). At a more local scale, specific gage locations tend to emphasize access (for example, bridges) and stable, well-behaved stagedischarge relationships (for example, at hydraulic controls). To counter the spatial clustering of gages, we constructed a Thessien polygon coverage attributing each gage by the area of landscape that was closer to it than to any other gage. We used these areas as weights in a random selection in which the probability of a gage being selected was proportional to the area of landscape closest to the gage - bigger areas associated with sparse gages having higher probabilities of selection. The set of 500 selected gages was further reduced to 476 that we actually visited based on access and the easily identified lack of a semi-natural site that could be associated with the gage. Finally, the 476 gages we visited were reduced to 456 included in this data set by dropping sites with substantial missing data (primarily in the daily hydrologic record), where we couldn't reasonably estimate the 30 -year flood plain, or where no site could be found that represented a semi-natural vegetation response to the streamflow measured at the gage (for example, because of the arrangement of diversions or tributaries, or essentially complete urban or agricultural land use in the bottomland).

At the scale of a specific site, the goal was to select a location that fairly represented the naturally established vegetation near the gage, rather than sampling exactly at the gage itself in order to avoid spanning the type of breakpoints (for example, hydraulic control, canyon mouth) where gages are often located. We were striving to map flood plain associated with $0.5-3 \mathrm{~km}$ of stream with the length roughly proportional to the flood plain width. Sites in the data set had a median mapped river length of $1.2 \mathrm{~km}$; a range of $0.14-6.4 \mathrm{~km}$; and first and third quartiles of 0.9 and $1.8 \mathrm{~km}$, respectively.

\section{Mapping and Vegetation}

All sites were visited during the growing seasons of 1996-2002 by one or more of a core team of six people (the authors and Michael D. Freehing, University of New Mexico). We trained together on multiple sites to increase consistency. At each site, we drew a map of the area estimated to have been inundated within the last 30 years (referred to as "flood plain") on an acetate overlay of a hard-copy aerial photograph. In cases where portions of the flood plain had been cleared of naturally established vegetation or isolated by levees or fill, we included these portions within the flood plain and then mapped them as excluded, anthropogenic polygons $(\mathrm{SPPCODE}=\mathrm{E}$, table 2). Where there had been an apparent reduction in flood plain width (resulting from arroyo cutting or flow regulation) within the last 150 years, we mapped the boundary of the flood plain before this reduction. The mapped flood plain generally contained all naturally established cottonwood at the site, but not all individuals of those woody species commonly occurring in both the flood plain and surrounding uplands (for example, green ash in central Kansas, or Englemann spruce in the Colorado mountains).

Within this mapped area we then defined a channel $(\mathrm{SPPCODE}=\mathrm{C}$, table 2$)$ polygon representing the active channel following Hedman and Osterkamp (1982), delineated by the lowest extent of established (> 1-year old) perennial vegetation, and in some cases by an abrupt decrease in slope with increasing height away from the thalweg. Channel polygons did not contain cover of any woody species. The active channel was generally wider than the width of water in the channel in the aerial photograph or on the ground at the time of sampling. In cases where the active channel was too narrow to draw as a polygon we drew a single line along the channel, recorded the average active channel width on the data sheet, and later constructed a polygon by a geospatial buffering operation.

We divided the remainder of the flood plain area into polygons of relatively homogenous woody composition and attributed them with the percent cover of each of the taxonomic categories in the defined species list (table 2) including a category of Other Large Woody for naturally occurring woody species $>1.5 \mathrm{~m}$ tall that were not on the pre-defined species list $(\mathrm{SPPCODE}=\mathrm{OLW}$, table 2 ). Only cover values of greater than 1 percent were recorded. Polygons not containing woody species with cover greater than 1 percent were coded bare $(\operatorname{SPPCODE}=\mathrm{B}$, table 2 ). Total cover within a polygon (summed across all species in the polygon) could exceed 100 percent when there were overlapping layers of different species. Subsequent geospatial analysis quantified the area for each polygon supporting aggregations such as total percent cover by species for the site as a whole, for the non-channel portion of the site, and fraction of total woody cover for each species. Occupancy was recorded for all species listed in table 2 even if they did not exceed the 1 percent cover value that was necessary for inclusion in any polygon

\section{Independent Variables}

We also estimated several indicators of possible independent variables in the field. The fraction of the bank that was stabilized (for example, riprap or dikes) was estimated for each side of the river. We estimated the median sediment size $\left(d_{50}\right)$ for the surface of the flood plain (the area between 


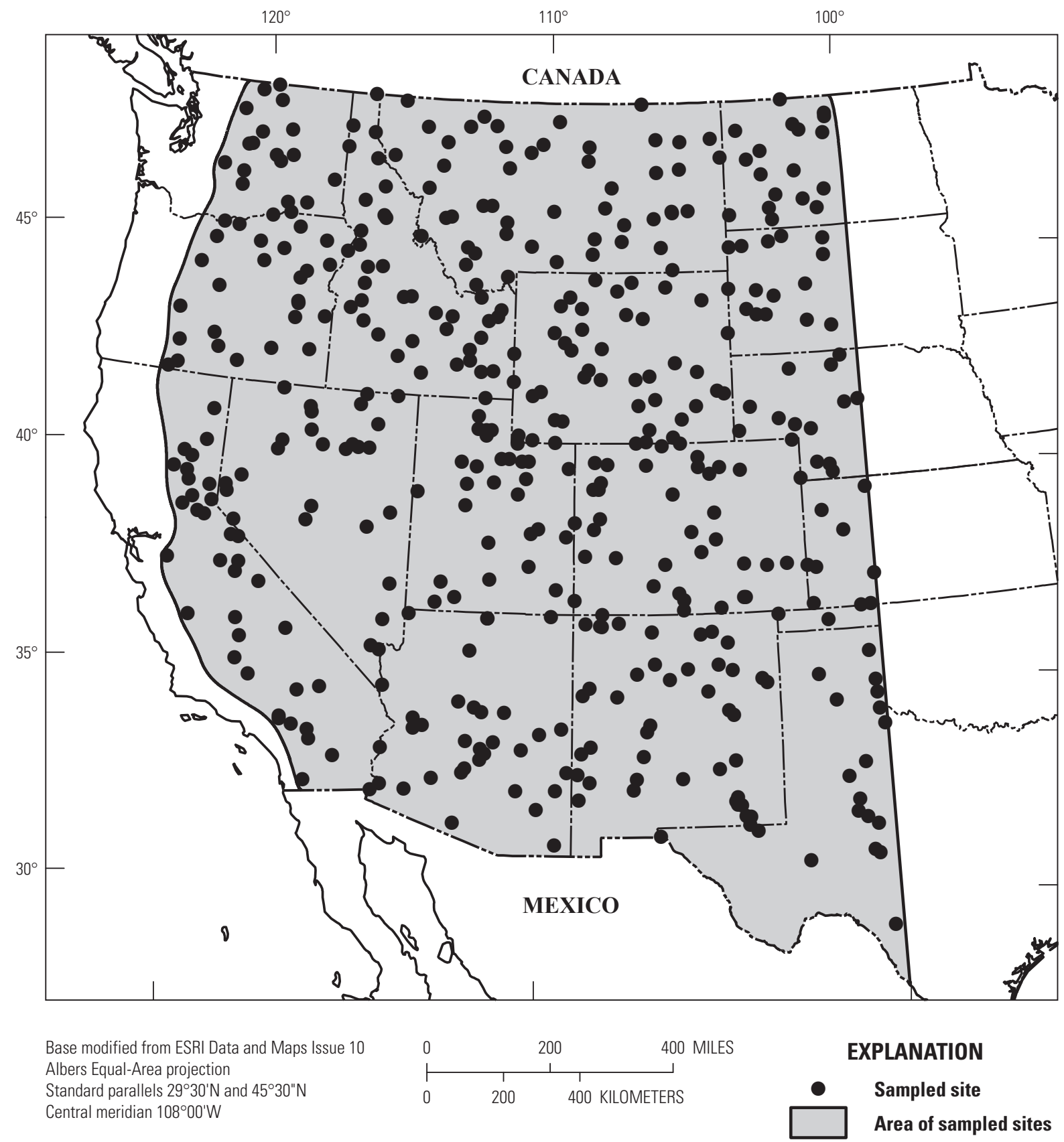

Figure 1. Locations of the 456 sampled sites. 
the active channel and flood plain boundary). We recorded the presence of high-salinity indicators on the flood plain such as salt crusts or abundant halophytes - being careful to avoid using any species in table 2, such as saltcedar, as a halophytic indicator species. We recorded observations of planted Russian olive or saltcedar within $5 \mathrm{~km}$ of the site, without spending any time searching for them beyond traveling to and from the site.

We assigned categorical indicator values for three aspects of grazing (table 1): herbaceous current use (4 levels), shrub current use ( 2 levels), and past use (4 levels). Following the field sampling we extracted several geometric measurements for each site using a combination of the digitized overlay, 7.5-minute USGS topographic maps, and the aerial photography. These included length of channel, and valley width and length corresponding to the mapped study site. We also estimated river gradient by applying elevations from topography maps to channel lengths from the mapped study site or a larger section of river containing the mapped study site. Where the gradient was very shallow, generally upstream of a natural or anthropogenic hydraulic control, we either estimated a maximum gradient or assigned a value of 0 gradient.

\section{Summary}

We have used this data set to characterize the importance of non-native trees in the current western riparian forests and to characterize the distribution of selected riparian trees with respect to climatic variables (Friedman and others 2005). Parts of the data set have also been used in work focused on individual species (Guilbault and others 2012; Katz and Shafroth 2003; Nagler and others 2010,2011) and in other distributional studies (Jarnevich and Reynolds 2010, Ringold and others 2008). We continue to examine the data set to evaluate the consistency of hypotheses generated from intensive studies with broad-scale patterns and encourage other investigators to use it for these or other purposes.

\section{Acknowledgments}

Tammy S. Fancher (USGS) digitized field maps and performed geospatial analysis. Peggy B. Anderson (Johnson Controls) coordinated logistics and equipment, compiled and proofed field data, and attributed field maps. Michael D. Freehling (University of New Mexico) sampled some of the field sites.

\section{References Cited}

Friedman, J.M., Auble, G.T., Shafroth P.B., Scott, M.L., Merigliano M.F., Freehling M.D., and Griffin E.R., 2005, Dominance of non-native riparian trees in western USA: Biological Invasions, v. 7, p. 747-751.

Guilbault, K.R., Brown C.S., Friedman J.M., and Shafroth, P.B., 2012. The influence of chilling requirement on the southern distribution limit of exotic Russian olive (Elaeagnus angustifolia) in western North America: Biological Invasions, v. 4, p. 1711-1724.

Hedman, E.R., and Osterkamp W.R., 1982, Streamflow characteristics related to channel geometry of streams in western United States: U.S. Geological Survey Water Supply Paper 2193, $17 \mathrm{p}$.

Jarnevich, C.S., and Reynolds L.V., 2010, Challenges of predicting the potential distribution of a slow-spreading invader-A habitat suitability map for Russian olive (Elaeagnus angustifolia) in the western United States: Biological Invasions, v. 13, p. 153-163.

Katz, G.L., and Shafroth P.B., 2003, Biology, ecology and management of Elaeagnus angustifolia L. (Russian olive) in western North America: Wetlands, v. 23, p. 763-777.

Nagler, P.L., Glenn E.P., Jarnevich C.S., and Shafroth P.B., 2010, Distribution and abundance of saltcedar and Russian olive in the western United States in Shafroth P.B., Brown C.A., and Merritt D.M., eds., Saltcedar and Russian olive control demonstration act science assessment: U.S. Geological Survey Scientific Investigations Report 2009-5247, p. 7-32.

Nagler, P.L., Glenn E.P., Jarnevich C.S., and Shafroth P.B., 2011. Distribution and abundance of saltcedar and Russian olive in the western United States: Critical Reviews in Plant Sciences, v. 30, p. 508-523.

Ringold, P.L., Magee T.K., and Peck D.V., 2008, Twelve invasive plant taxa in US western riparian ecosystems: Journal of the North American Benthological Society, v. 27, p. $949-966$.

U.S. Department of Agriculture (USDA), 2004, The PLANTS Database, ver. 3.5 : Baton Rouge, La., U.S. Department of Agriculture, National Plant Data Center. Accessed on Jan. 08, 2004 at http://plants.usda.gov.

U.S. Geological Survey, 2012, Surface-water data for the Nation: U.S. Geological Survey, National Water Information System, available at $h t t p: / / w a t e r d a t a . u s g s . g o v / n w i s / s w$. 
Publishing support provided by:

Denver Publishing Service Center

For more information concerning this publication, contact: Center Director, USGS Fort Collins Science Center

2150 Centre Ave., Bldg. C

Fort Collins, CO 80526-8118

(970)226-9398

Or visit the Fort Collins Science Center Web site at: http://www.fort.usgs.gov/ 


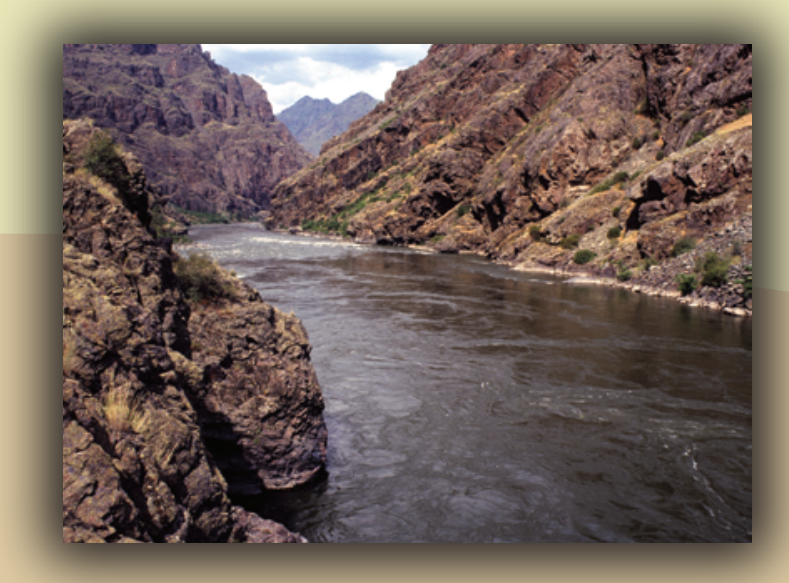

咅

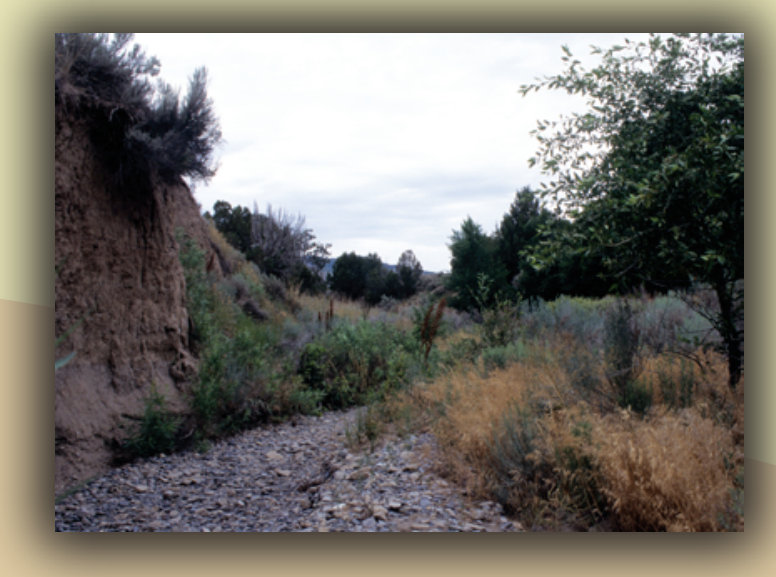

政

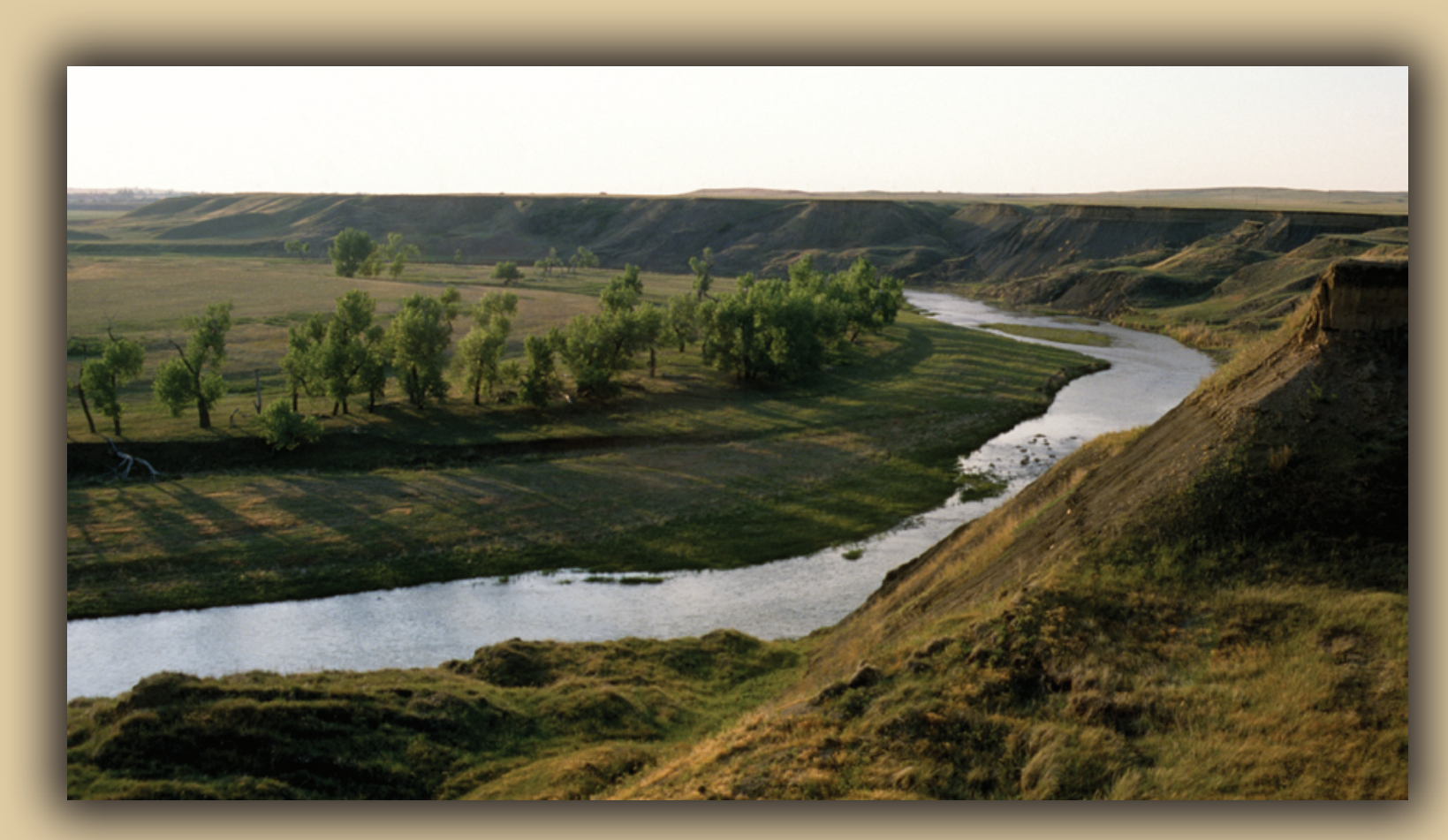

